\title{
Effect of raw and cooked mucuna seed meal based diets on the performance, nutrient digestibility and haematology of weaned rabbits
}

\author{
A. A. Taiwo .A. D. Adejurigbe ${ }^{2}$, E.O. Talabi², G. Okumakuma ${ }^{2}$ and \\ E. A. Adebowale:
} Institute of Agricultural Research and Training (IAR \&T), Obafemi Awolowo University, P. M.
B. 5029 . Ihadan, Nigeria 'Federal College of Animal Health and Production Technology, IAR \& T, P. M. B. 5029, Ihadan,
Vigeria.

\begin{abstract}
A study was conducted for eight weeks to determine the effect of raw and cooked mucuna seed meal (MSM) based diets on the performance and haematological characteristics of cross-bred weaned rabbits. Three experimental diets were formulated to contain: $0 \%$ MSM (control /diet $\therefore, \ldots$ raw MSM (diet B) and $20 \%$ cooked MSM (diet C). Twelve cross-bred weaned rabbits with mean initial live-weight of about $550 \mathrm{~g}$ were randomly assigned to the three dietary treatments. The experimental design used was completely randomized arrangement. The feed intakes $(115.12,114.44$, $116.15 \mathrm{~g} /$ doy) and weight gains $(17.19,12.72,14.28 \mathrm{~g} /$ day) for diets $A, B$ and $C$ respectively were similar $(P>0.05)$ for the three treatments. Rabbits fed the control diet $A$ had the best $(P<0.05)$ feed conversion ratio $(6.68)$. The packed cell volume $(P C V)$, haemoglobin $(H B)$, red blood cell $(R B C)$ and white blood cell (WBC) values obtained for the three treatments were not statistically different ( $P>0.05$ ) from one another. The $H b, R B C, W B C$ values of rabbits fed on $20 \%$ cooked $M S M$ based diet had comparable values to those on the control diet. Based on the weight gain and the haematology, 20\% cooked mucuna seed meal can be included in the diet of weaned rabbits.
\end{abstract}

Keywords: Mucuna seed meal, rabbits, weight gain, haematology.

Introduction

An average Nigerian does not consume enough of protein of animal origin that nourishes the body and needed for tissue development, repairs and healthy living (.FA.O.,1993). This has led to serious mainutrition especially among the vulnerable groups (e.g children and poor/low class people) that form the majority in the society.

The intensification of livestock production is one way out of the present nutritional predicament facing the country. Rabbit production has some advantages over poultry in that it is not capital intensive and the animals can make use of forage as part of their diet. Also, rabbit production has some advantages over cattle, sheep and goat production in that it requires little space to rear them. This makes it convenient for resource poor people and those with small land holding to keep. Their feed requirement is also smaller. Nevertheless, improvement in rabbit production requires the feeding of concentrate as supplement to forages (Butcher et al, 1980). 
The conventional feed ingredients particularly those of protein origin used in feed formulation such as soyabean cake and groundnut cake are expensive. This has necessitated the search for alternative feed resources. Mucuna pruriens (velvet bean) is an under utilized legume. It is high in crude protein (Afolabi et al 1985), thus has high potentials as an ingredient for livestock feeding. However, the use of Mucuna pruriens is limited by its high content of toxins and antinutritional factors (Liener, 1994). It has been reported to contain trypsin inhibitors, phytates, cyanogenic glucosides, tannins and L-3, 4 dehydroxyphenylalanine (L-DOPA) (Ravindran and Ravindran, 1988; Mary Josephine and Janardhanan, 1992). It has however been observed that except for L-DOPA, all the antinutritional factors detected in the seeds are heat labile and could be eliminated by cooking (Mary Josephine and Janardhanan, 1992).

Earlier studies have shown that broiler chicks could not tolerate more than $5 \%$ raw mucuna seed in their diet (Esonu, 2001). Heat treatment has been found to improve the in-vitro protein digestibility of mucuna seed over the raw seed (Iyayi and Egharevba, 1998). Inclusion of $10 \%$ raw or toasted mucuna seed in broiler finisher diets depressed the growth rate compared to cooked mucuna seed (Emenalom and Udedibie, 1998). However, at $20 \%$ level of inclusion in the diet, cooked mucuna seed meal also depressed the growth rate of broiler finishers.

Few data are available on the use of mucuna seed meal in rabbit feeding. Emenalom et al (2001) found that both dehulled and cooked mucuna seed meal at $10 \%$ level increased the feed intake of rabbits without affecting their growth rate. There is the need to explore higher levels of mucuna seed meal utilization in rabbit diet. Thus, the objectives of this study were to find the effects of raw and cooked mucuna seed meals at $20 \%$ level in the diets of rabbits on their feed intake, growth rate, feed conversion ratio and haematology.

\section{Materials and Methods}

This study was conducted at the Rabbitary unit of the Federal College of Animal Health and Production Technology, IAR\&T., Ibadan. Raw seeds of Mucuna pruriens (velvet bean) were ground and some cooked at boiling point $\left(96^{\circ} \mathrm{C}\right)$ for 60 minutes. The cooked seeds were sun-dried and ground before including in the diet. Table 1 shows the ration composition of the diets. The diets were formulated to be iso-nitrogenous with about $17.55 \%$ crude protein (CP). There were three treatments comprising $0 \%$ mucuna seed meal (MSM) (control), 20\% raw mucuna seed meal (RMSM) and 20\% cooked mucuna seed meal (CMSM) in diets $A, B$, and $C$ respectively. Twelve cross-bred weaned rabbits with average initial live-weight of about $550 \mathrm{~g}$ were randomly assigned to the three experimental diets with four rabbits per treatment each serving as a replicate. The experimental design used was completely randomized arrangement. The animals were housed individually in separate hutches. There was a two -week adjustment period prior to the trial and the experiment lasted for eight weeks. Feed and water were provided ad libitum twice daily; moming and afternoon. The feed intake was measured daily while weight changes were taken on weekly basis.

The proximate analysis of raw and cooked mucuna seed meals and experimental diets was carried out on duplicate samples using A. O. A. C.(1995) methods. The gross energy values in the meals and diets were calculated by Pauzenga (1985) equation: $\mathrm{GE}(\mathrm{Kcal} / \mathrm{Kg})=5.72 \mathrm{CP}+95.0$ $\mathrm{EE}+47.9 \mathrm{CF}+41.7 \mathrm{NFE}$ where GE,CP, EE, CF, NFE are gross energy, crude protein, crude fibre and nitrogen free extract respectively.

Blood samples were collected at the 8th week of the trial from three rabbits per treatment via the marginal ear vein in the evening around $17.00 \mathrm{hr}$. The samples were collected in bottles containing ethylene tetra-acetic acid (EDTA) as anticoagulant. They were then taken to the 
Table 1: Composition of the experimental diets (\%).

\section{TREATMENTS}

\begin{tabular}{llll} 
Ingredients & $\begin{array}{c}\text { Diet A (Control) } \\
(\mathbf{0 \%} \text { MSM) }\end{array}$ & $\begin{array}{c}\text { Diet B } \\
(\mathbf{2 0} \% \mathbf{R M S M})\end{array}$ & $\begin{array}{c}\text { Diet C } \\
(\mathbf{2 0} \% \mathbf{C M S M})\end{array}$ \\
\hline Maize cob & 19.00 & 19.00 & 19.00 \\
Maize offals & 42.00 & 38.00 & 38.00 \\
Soyabean meal & 26.00 & 15.00 & 15.00 \\
MSM & 0.00 & 20.00 & 20.00 \\
Wheat offals & 10.00 & 5.00 & 5.00 \\
Bone meal & 2.00 & 2.00 & 2.00 \\
Salt & 0.50 & 0.50 & 0.50 \\
Vitamin/mineral & 0.50 & 0.50 & 0.50 \\
premix & & & \\
& & 100 & 100 \\
Total & 100 & & \\
\hline MSM: Mucuna seed meal, RMSM: Raw mucuna seed meal, CMSM: Cooked \\
mucuna seed meal
\end{tabular}

laboratory for haematological analyses which included packed cell volume (PCV), erythrocyte (red blood cell), leucocytes (white blood cell) and haemoglobin. Haematological parameters were determined as described by Davice and Lewis (1991). Data were analysed by analysis of variance technique (Steel and Torrie 1980), while significant means were separated by least significant difference method.

\section{Results and Discussion}

The proximate composition of raw (RMSM) and cooked mucuna seed meals (CMSM) and the three experimental diets is shown in Table 2. Cooked MSM had lower content of crude protein $(24.08 \%)$, crude fibre (6.29) and ether extract (3.05\%) compared to the raw sample with values of $29.23 \% \mathrm{CP}, 8.22 \% \mathrm{CF}$ and $3.20 \% \mathrm{EE}$. However, the cooked MSM contained higher levels of ash, nitrogen free extract and gross energy. The crude protein (CP) content of raw and cooked mucuna seed meals corresponds with the report of Siddhuraju et al (1996) which stated that the $\mathrm{CP}$ of Mucuna pruriens ranged between 24 and $32 \%$.
The lower values for $\mathrm{CP}, \mathrm{CF}$ and $\mathrm{EE}$ in the cooked MSM could be due to cooking effect leading to solubilization of nutrients into the cooking water. This agrees with the findings of Emenalom and Udedibie (1998) that cooking tended to reduce the crude protein content of mucuna seeds possibly due to solubilization of some nitrogenous compounds. The crude fibre level in cooked MSM is also supported by the report of Aletor and Ojo (1989).

Data on feed intake, weight changes and feed conversion ratio of the rabbits on the diets are shown in Table 3. The inclusion of $20 \%$ raw mucuna seed in the diet slightly depressed the feed intake and weight gain of the rabbits. The highest feed intake $(116.15 \mathrm{~g} /$ day $)$ and weight gain $(17.19 \mathrm{~g} /$ day) were recorded on diet $\mathrm{C}$ (CMSM) and $\operatorname{diet} A$ (control) respectively. However, there were no significant differences ( $P>0.05$ ) among the diets in the two parameters. The slightly high feed intake on diet C (CMSM) could be due to the cooking of the mucuna seed which makes the nutrients more available and the diet more palatable, thus enhancing feed intake. It could also be due to the slightly lower 
Taiwo, Adejuyigbe, Talabi, Okumakuma and Adebowale

Table 2: Proximate composition of raw, cooked mucuna seed meals and experiments diets ( $\mathrm{g} / 100 \mathrm{DM}$ ).

\begin{tabular}{llllll}
\hline Parameters & $\begin{array}{l}\text { Raw } \\
\text { MSM }\end{array}$ & $\begin{array}{l}\text { Cooked } \\
\text { MSM }\end{array}$ & $\begin{array}{l}\text { Diet A } \\
\text { control } \\
(\mathbf{0} \% \mathbf{M S M})\end{array}$ & $\begin{array}{l}\text { Diet B } \\
\mathbf{( 2 0 \%} \\
\text { RMSM) }\end{array}$ & $\begin{array}{l}\text { Diet C } \\
(\mathbf{2 0 \%} \\
\text { CMSM) }\end{array}$ \\
\hline Dry matter & 90.40 & 90.02 & 89.78 & 90.10 & 89.88 \\
Crude protein & 29.23 & 24.08 & 16.72 & 17.37 & 17.19 \\
Crude fibre & 8.22 & 6.29 & 9.99 & 11.26 & 10.30 \\
Ether extract & 3.20 & 3.05 & 4.81 & 5.51 & 5.21 \\
Ash & 4.0 & 4.23 & 8.80 & 10.06 & 9.80 \\
Nitrogen free extract & 45.72 & 52.37 & 49.46 & 45.90 & 47.37 \\
Gross energy (Kcal/kg) & 2771.46 & 2912.61 & 3099.43 & 3076.19 & 3062.93 \\
\hline \hline
\end{tabular}

MSM: Mucuna seed meal, RMSM: Raw mucuna seed meal, CMSM: Cooked mucuna seed meal

energy content of the diet, which makes the animals to eat more in order to satisfy their energy requirement. The similarity in feed intakes recorded among the diets is opposed to the depression in feed intake noted in broiler finishers when $20 \%$ cooked MSM was incorporated in their diet (Emenalom and Udedibie, 1998). The non significant increase in weight gain in diet $\mathrm{A}$ (control) could be due to the absence of mucuna seed meal and hence its anti-nutritional factors that could have imparted negative effect on utilization of nutrients particularly protein (Moseley and Griffiths, 1979). The weight gain recorded in rabbits fed $20 \%$ cooked MSM (diet C): $14.28 \mathrm{~g} /$ day in this study is comparable with the value of $14.45 \mathrm{~g} /$ day for rabbits fed $10 \%$ CMSM diet (Emenalom et al 2001). However, Emenalom and Udedibie (1998) found that $20 \%$ cooked Mucuna pruriens seed meal in the diet of broiler finisher significantly depressed their growth rare. The value recorded for $20 \%$ RMSM; $12.72 \mathrm{~g} /$ day in this study is lower than that obtained for $10 \%$ RMSM diet; $15.45 \mathrm{~g} /$ day in another study (Emenalom et al 2001). It is also reported by Ukachukwu et al, (2002) that $0.25 \%$ methionine supplementation of $10 \%$ boiled mucuna seed meal diet fed to broiler finisher substantially improve the daily weight gain (about $60 \%$ ) over the un-supplemented diet.

Table 3: Performance of rabbits fed raw and cooked mucuna seed meal diets.

\begin{tabular}{lllll}
\hline Parameters & $\begin{array}{l}\text { Diet A } \\
(\mathbf{0 \%}\end{array}$ & $\begin{array}{l}\text { Diet B } \\
\mathbf{( 2 0 \%} \\
\text { MSM) }\end{array}$ & $\begin{array}{l}\text { Diet C } \\
(\mathbf{2 0} \% \mathbf{C M S M})\end{array}$ & SED \\
\hline Total feed intake (g) & 6446.88 & 6408.81 & 6504.62 & 275 \\
Av, feed intake(g/day) & $115.12^{\mathrm{a}}$ & $114.4^{\mathrm{a}}$ & $116.15^{\mathrm{a}}$ & 4.91 \\
Initial body weight $(\mathrm{g})$ & 562.5 & 550 & 575 & \\
Final body weight $(\mathrm{g})$ & 1525 & 1262 & 1375 & \\
Actual weight gain $(\mathrm{g})$ & 962.5 & 712.5 & 800 & 1.63 \\
Weight gain/day (g) & $17.19^{\mathrm{a}}$ & $12.72^{\mathrm{a}}$ & $14.28^{\mathrm{a}}$ & 0.63 \\
\hline Feed conversion ratio & $6.68^{\mathrm{b}}$ & $9.03^{\mathrm{a}}$ & $\mathbf{8 . 2 4 ^ { \mathrm { a } }}$ & \\
\hline
\end{tabular}

\footnotetext{
a,b.c: Means within a row with similar superscripts are not significantly different ( $P>0.05$ ), MSM: Mucuna seed meal, RMSM: Raw mucuna seed meal, CMSM: Cooked mucuna seed meal, SED: Standard error of difference.
} 
The control diet $A$ had the best $(\mathrm{P}<0.05)$ feed conversion ratio (FCR) (6.68) while the poorest FCR was recorded on the raw MSM based diet B (9.03). However, there was no significant difference in the FCR values between the raw and cooked mucuna seed meal diets. The FCR values obtained with graded levels of raw pigeon pea seed in the diets of weaned rabbits (Amaefule et $a l, 2004$ ) were better ( 1.63 to 2.38) than values recorded in this study. No mortality was recorded during the experiment. This indicated that both the raw and cooked mucuna seed meal diets did not have any deleterious effect on the experimental animals. Table 4 shows the haematological characteristics of rabbits fed raw and cooked mucuna seed meal diets. There were no significant differences $(P>0.05)$ among the diets in the parameters measured. The PCV value for rabbits on the control diet A was within the normal physiological range while those obtained for the animals on mucuna based diets were slightly below the normal range (Olomu et al, 2003). The haemoglobin values recorded for all the diets were within the normal range of values (Scarbourgh, 1932 quoted by Schalm, 1965).

The RBC values recorded in this study are lower than the range of $6-11 \times 10^{6}$ per $\mathrm{mm}^{3}$ of blood (Olomu et al, 2003). However, rabbits on the control diet $A$ and $20 \%$ cooked mucuna meal diet $C$ had values within the range 4.5-7.0 $\times 10^{6} /$ $\mathrm{mm}^{3}$ stated by another author (Scarbourgh, 1932 quoted by Schalm, 1965). The WBC values recorded in this study: $4.07-5.6 \times 10^{3}$ per $\mathrm{mm}^{3}$ of blood are with the range of $4-13 \times 10^{3} / \mathrm{mm}^{3}$ given by Scarborough (1932). The haemoglobin, $\mathrm{RBC}$ and WBC values of rabbits fed on the $20 \%$ cooked MSM diet $\mathrm{C}$ had comparable values to those on the control diet $\mathrm{A}$ and the values are within normal physiological range (Schemer 1954; Scarbourgh, 1932 quoted by Schalm, 1965). The study of Akinmutimi and Abasiekong (2002) demonstrated that the inclusion of $20 \%$ cooked Mucuna utilis seed meal in the diet of broiler finisher birds could replace soyabean meal without any adverse effect based on the biochemical and haemotological indices. In this study, inclusion of $20 \%$ raw and cooked mucuna seed meal in the diets of weaned rabbits promoted good weight gain. However, there is the need for caution in including $20 \%$ raw mucuna seed meal in rabbits' diet because of the depression of the red blood cell values of the animals on this diet.

\begin{tabular}{lllll}
\hline $\begin{array}{l}\text { Haematological } \\
\text { characteristics }\end{array}$ & $\begin{array}{c}\text { Diet A } \\
(0 \% \text { MSM })\end{array}$ & $\begin{array}{c}\text { Diet B } \\
(\mathbf{2 0 \%} \text { CMSM })\end{array}$ & $\begin{array}{c}\text { Diet C } \\
(\mathbf{2 0 \%} \text { CMSM })\end{array}$ & SED \\
\hline PCV (\%) & 41.33 & 33.00 & 27.33 & 9.11 \\
Haemoglobin (g & 13.8 & 11.0 & 9.10 & 3.02 \\
$/ 100 \mathrm{ml})$ & & & & \\
RBC $\left(\right.$ per $\left.\mathrm{mm}^{3}\right)$ & $4.67 \times 10^{6}$ & $3.10 \times 10^{6}$ & $4.43 \times 10^{6}$ & $1.48 \times 10^{6}$ \\
WBC (per $\left.\mathrm{mm}^{3}\right)$ & $5.6 \times 10^{3}$ & $4.33 \times 10^{3}$ & $4.07 \times 10^{3}$ & $1.17 \times 10^{3}$ \\
\hline \hline
\end{tabular}

MSM: Mucuna seed meal, RMSM: Raw mucuna seed meal, CMSM: Cooked mucuna seed meal, SED: Standard error of difference, PCV : Packed cell volume, RBC : Red blood cell, WBC : White blood cell.

\section{Conclusion}

Cross-bred weaned rabbits fed on $20 \%$ raw mucuna seed meal (MSM) based diet had comparable performance to the control diet without MSM and the $20 \%$ cooked MSM based diets in terms of feed intake and weight gain.
However, the $20 \%$ raw MSM based diet depressed the red blood cell in rabbits compared to $20 \%$ cooked MSM based diet. Therefore, $20 \%$ cooked mucuna seed meal can be included in the diet of weaned rabbits while $20 \%$ raw mucuna seed meal should be used with caution. 


\section{References}

Afolabi O. A., B. A Osuntogun., S. R Adewusi., O. O Fapojuwo., F. O Ayorinde, F. E Grissom and O. L. Oke 1985. Preliminary nutritional and chemical evaluation of raw seeds from Mucuna solanei: an underutilized food source. I Agric. Food Chem 33: 122 - 124.

Akinmutimi A. H. and S. F. Abasiekong 2002. Effect of quantitative replacement of soyabean with cooked Mucuna utilis seed meal on blood constituent values of broiler finisher birds. In : Proc 7th Ann. Conf. Anim. Sci Ass. of Nig. Sept 16-19, 2002 , held at Univ. of Agric. Abeokuta, Nigeria, pp $115-117$.

Aletor V. A. and O. I. Ojo 1989. Changes in differently processed soyabean (Gycine max) and (Phaseolus lunatus) with particular reference to the chemical composition and their mineral and inherent anti-nutritional constituents. Nahrung 33: $1009-1016$.

Amaefule K.U, C.C.Nwaokoro and F.C. Iheukwumere. 2004. The effect of feeding graded levels of raw pigeon pea seed (Cajanus cajun) meal on the performance, nutrient retention and carcass characteristics of weaned rabbits . Nig. J. Anim. Prod. 31: 194-199.

Association of Official Analytical Chemists (A.O.A.C.) 1995. Official Methods of Analysis 16th Edition Washington D. C.

Butcher C, M.J. Bryant and E. Owen. 1981.Effect of metabolizable energy concentration on performance and digestibility in growing rabbits. Trop. Anim. Prod. 6: 93-100.
Davice J.U. and S.M. Lewis. 1991. Practical haematology $8^{\text {th }}$ edition Longman Ltd. London, pp 22-68.

Emenalom O.O, A.B.I. Udedibie and B. $O$. Esonu 2001. Comparative evaluation of raw, dehulled and cooked Mucuna pruriens (Velvet bean) seeds on the diets of weaned rabbits. In : Proc 26th Ann. Conf. Nig. Soc. Anim Prod held at NAPRI, Zaria, Nigeria pp187-188.

Emenalom O. O. and A.B. I. Udedibie. 1998. Effect of dietary raw, cooked and toasted Mucuna pruriens seeds (Velvet bean) on the performance of finisher broilers. Nig. $J$. Anim. Prod 25: 115 - 119 .

Esonu B. O. 2001. Comparative evaluation of raw and urea/toasted velvet bean (Mucuna Pruriens) for broiler chicks. Nig. J. Anim. Prod. 28: 40 - 44.

Food and Agricultural Organization. 1983. Production Year Book, Vol. 47, Rome, Italy.

Iyayi E. A. and J. I.Egharevba. 1998. Biochemical evaluation of seeds of an under utilized legume (Mucuna utilis) Nig. J. Anim. Prod 25: 40-45

Mary Josephine R. M. and K Janardhanan. 1992. Studies on chemical composition and anti-nutritional factors in three germplasm seed materials of the triabal pulse (Mucuna oruriens) (L) DC. Food Chem. 43: 13-18.

Liener I. E. 1994. Implications of antinutritional components in soyabean foods.Crit. Rev. Food Sci. Nutri. 34: 31 67.

Mosley G. and D. W. Griffiths. 1979. Varietal variation in the anti-nutritive effects of field beans (Vicia faba) when fed to rat. J. Sci. Food. Agric. 30: $772 \sim 778$. 
Taiwo, Adejuyigbe, Talabi, Okumakuma and Adebowale

Olomu J.M., V.E. Ezieshi and A.M. Orheruata. 2003. Comparative physiological, haematological, reproductive and physical characteristics of grass-cutter, rabbit and pig In: Grass-cutter production in Nigeria: Principles and.Practice, A Jachem Publication pp: 46.

Pauzenga U. 1985. Feeding parent stock. Zootecnica International Dec. 1985 pp: $22-$ 24.

Ravindran $V$ and G. Ravindran, 1988. Nutritional and anti-nutritional characteristics of mucuna (Mucuna utilis) bean seeds. J. Sci. Food Agric., 46: 71-99.

Scarborough R.A. 1932. The blood picture of normal laboratory animals. A compilation of published data. Yale Y. Biol. and Med. J.: ( rabbits) 64; (guinea pig ) 169; (rat) 267; (mouse) 272 and (monkey) 199: 19311932.

Schermer S. 1954. Die blutmorphologie der laboratoriumstiere. Barth, Leipsig

Schalm O.W. 1965. Veterinary haematology, Lea and Febiger, Philadelphia $2^{\text {nd }}$ edition.

Siddhuraju P, Vijayakumari K., K. Janardhana. 1996. Chemical composition and protein quality of the little known legume velvet bean (Mucuna pruriens) (L) DC. J. Agric. Food Chem. 44:26362641 .

Steel R. G. D. and J. H. Torrie. 1980. Principles and Procedures of Statistics. A biometric Approach, 2ndEdition. McGraw Hill Book co., New York.

Ukachukwu S. N., S.O.Uzoechi and S.C. Akomas. 2002. Effect of methionine supplementation on the growth performance of starter broilers fed Mucuna cochinchinensis. In : Proc. 27th Ann. Conf. Nig. Soc. For Anim. Prod. March 17-21, held at Fed. Univ. of Tech. Akure, Nigeria, p: 160-163.

(Received 21 August 2004: Accepted 15 October 2005) 